\title{
MORPHOGENESIS AND MECHANISMS OF PENETRATION BY PLANT PATHOGENIC FUNGI
}

\author{
K. Mendgen, M. Hahn, and H. Deising \\ Universität Konstanz, Fakultät für Biologie, Lehrstuhl für Phytopathologie, \\ Universitätsstrasse 10, D-78434 Konstanz, Germany
}

KEY WORDS: penetration, fungi, cell wall-degrading enzymes, infection structures

\begin{abstract}
Infection structures of phytopathogenic fungi are modified hyphae specialized for the invasion of plant tissues. Initial events are adhesion to the cuticle and directed growth of the germ tube on the plant surface. At the site of penetration, appressoria are often formed that may have melanized walls and develop high turgor pressure to support the penetration process. The penetration hypha accumulates components of the cytoskeleton in the tip and secretes a variety of cell wall-degrading enzymes in a highly regulated fashion in order to penetrate the cuticle and the plant cell wall. This article reviews recent papers on the cytology, physiology, and molecular biology of the penetration process.
\end{abstract}

\section{INTRODUCTION}

Plant parasitic fungi have conquered the living plant as a copious source of nutrients. For successful parasitism, a crucial step is penetration. In order to overcome the various barriers present in leaves, stems, or roots, fungi have evolved astonishingly diverse invasion strategies. For this purpose, infection structures are produced that enable the fungus to penetrate different types of plant cell walls. The morphogenetic events leading to formation of the infection structure often depend on specific signals provided by the plant surface and are prerequisites for a particular mode of penetration. Physiological changes such as targeted secretion of enzymes or an increase of pressure within the infection structure support the penetration process. We believe that infection structures have evolved from nonpathogenic hyphae that are able to penetrate into their substrate. 
To understand the mechanisms of penetration, the peculiar properties of plantpenetrating hyphae must be distinguished from those shared with saprophytic hyphae growing through nonliving organic substrata. This distinction is not yet possible for many fundamental aspects, e.g. the role of cell wall-degrading enzymes, in the penetration process. Pathogenic fungi exhibit various degrees of specialization. Hyphae of Cladosporium fulvum increase in diameter immediately after growth through the open stomata and the avr 9 gene product is only produced during this advanced stage of fungal development (110a). Root pathogens such as Fusarium oxysporum or Rhizoctonia solani accumulate hyphae that may form infection cushions before individual hyphae penetrate with minor modifications of their morphology. More elaborate structures are differentiated by leaf pathogens such as Colletotrichum spp. or Magnaporthe grisea. These pathogens produce germ tubes that differentiate melanized appressoria from which penetration hyphae develop. The most sophisticated differentiation is observed in biotrophic rust fungi in the dikaryophase; these invade the intercellular space of the leaf with a complex series of infection structures until haustoria are produced within plant cells.

New techniques have contributed to a better understanding of these processes. Cryofixation has improved the preservation of cell organelles and membranes and has revealed new wall layers at the penetration site. Molecular components of the plant parasite interface have been recognized with immuno-electron microscopy. Using molecular genetic techniques, genes thought to be involved in the penetration process have been cloned and tested for their importance by targeted gene disruption.

This article focuses on important processes during penetration by pathogenic fungi into their host plants. Recent work dealing with interactions involving mycorrhizal fungi has been reviewed by Bonfante \& Perotto (7) and Cairney $\&$ Bruke (12) and is not discussed here. We have selected from the vast body of literature just those recent citations that have significantly contributed to our understanding of the penetration process.

\section{APICAL GROWTH OF HYPHAE}

Germ tubes and hyphae elongate by apical deposition of wall glycoproteins and polysaccharides such as chitin and glucans $(115,116)$. During extension of the fungal apex, these components are assembled into microfibrils as a result of hydrogen bonding and crosslinking of adjacent polysaccharide chains. Another minor component of some hyphae is melanin (26). Chitin and $\beta$-1,3-glucans are synthesized by transmembrane enzymes. The wall proteins or glycoproteins are processed in the Golgi apparatus or Golgi-equivalent $(52,67)$. Vesicles leaving the Golgi migrate to the hyphal tip and interact in the middle of the apex with an 
accumulation of vesicles, called the Spitzenkörper (36). This structure is very often visible by light microscopy as a refractory body. The Spitzenkörper seems to function as a center of microtubule nucleation and organization (93). In addition, it is a source of directional mass transport of vesicles toward the hyphal apex $(41,65)$. The Spitzenkörper may also control vesicle-mediated secretion of enzymes required for host cell wall degradation. For example, in Phytophthora infestans, a subpopulation of apical vesicles was shown to contain pectin methylesterase (32). In plant pathogens, the Spitzenkörper is eccentric and is closer to the substrate. Thus, the parasite appears to grow "nose down," which may help to recognize topographical features of the plant surface $(18,62,89)$.

An important feature of the hypha is the mechanism of forward movement at the apex. Hyphae of Saprolegnia ferax grown at full turgor (0.44 MPa) are able to penetrate into the agar medium. When the turgor of the fungus was decreased by increasing concentrations of osmolytes in the medium, the ability of the hyphae to penetrate agar was reduced concomitantly. However, reduction of turgor pressure to less than $0.02 \mathrm{MPa}$ did not affect the ability of the hyphae to grow forward on the agar surface (71). Thus, turgor pressure constitutes an essential component of fungal penetration ability, whereas forward movement and the shape of the hyphal tip appear to be mediated mainly by cytoskeletal elements such as actin filaments (41). Hyphal growth is directed in such a way as to explore the environment (39). Thigmotropic responses direct germ tubes on leaf surfaces (44). This mode of growth enables some plant pathogens to recognize an array of anticlinal walls or the stomatal opening (45, 89). Mechano-sensitive ion channels in the fungal plasma membrane may be involved in recognition (122), but the signal transduction pathway leading from signal perception to directional growth is not yet understood.

With the ability of the hyphae to sense the surface, to secrete cell walldegrading enzymes, and to exert pressure to the substratum beneath (63), the fungus has to modulate these tools in order to penetrate the host wall.

\section{HYPHAL ADHESION AND PREPARATION OF THE INFECTION COURT}

Hydrophobic interaction between spore and cuticle has been observed in many foliar pathogens $(19,27)$. This initial, nonmetabolic (passive) adhesion is followed by a second stage involving secretion of a film ensheathing the germ tube and parts of the cuticle in the vicinity of the hypha $(10,14,51,70,73)$. These fungal sheaths, which are associated with germ tubes of Botrytis cinerea $(28,92)$, rusts such as $U$. viciae-fabae (19) and Puccinia sorghi (16), and many other fungi, are assumed to mediate adhesion. 
Germlings of $B$. cinerea adhering to artifical surfaces were resistant to removal when treated with hydrolytic enzymes including protease, acids, or boiling (28). In contrast, protease treatment of rust germlings resulted in detachment $(16,29)$. Thus, in some fungi, proteins or glycoproteins present in the extracellular matrix support adhesion and enable hyphae to sense the surface and to differentiate infection structures $(14,29,119)$, whereas in others, carbohydrates seem to be involved in adhesion (74). At the macroconidial tip of Nectria haematococca, the mucilage and a $90-\mathrm{kDa}$ glycoprotein are specifically associated with adhesion (63a). With monoclonal antibodies, stage-specific glycoproteins have been identified as cell surface components from spores and infection structures of Colletotrichum lindemuthianum and Botrytis cinerea (80a, 19b). Experimental proof for the involvement of these molecules in adhesion has not yet been obtained by directed mutagenesis.

In Colletotrichum graminicola, the extracellular matrix embedding conidia contains several enzymes (74), some of which were identified as cutinases (83). Likewise, conidia of the powdery mildew fungus Erysiphe graminis f. sp. hordei release a liquid containing cutinase after landing on any hard surface (76, 84). Enzymes in the liquid are thought to erode the cuticle (60). Cutinase and esterase activities in the matrix surrounding rust uredospores have been demonstrated to contribute to spore adhesion to the leaf cuticle (24). Interestingly, appressoria of powdery mildew of barley are preferentially formed after contact with hydrophilic surfaces, and it has been demonstrated that the area covered by the conidial liquid is converted from a hydrophobic to a hydrophilic state, possibly by cutinases that hydrolize the cutin polymer (75). Thus, enzymes that are either present in the extracellular matrix covering germ tubes or spores, or released from these structures, may contribute to adhesion and preparation of the infection court.

Terhune \& Hoch (110) found that the degree of adhesion of germlings of $U$. appendiculatus to artificial surfaces correlated closely with substratum hydrophobicity. A class of abundant cell wall proteins called hydrophobins mediates adhesion by forming an amphipathic protein layer between hyphal wall polysaccharides and the hydrophobic plant cuticle $(115,118)$. Mutants of $M$. grisea with a disruption in the hydrophobin-encoding MPG1 gene showed strongly impaired ability to form appressoria and to cause lesion development on rice leaves (107).

\section{PENETRATION WITH MINOR MODIFICATIONS OF HYPHAE}

Several plant pathogenic fungi penetrate their host without differentiation of a fully developed (= septate) appressorium. The root pathogen Fusarium 


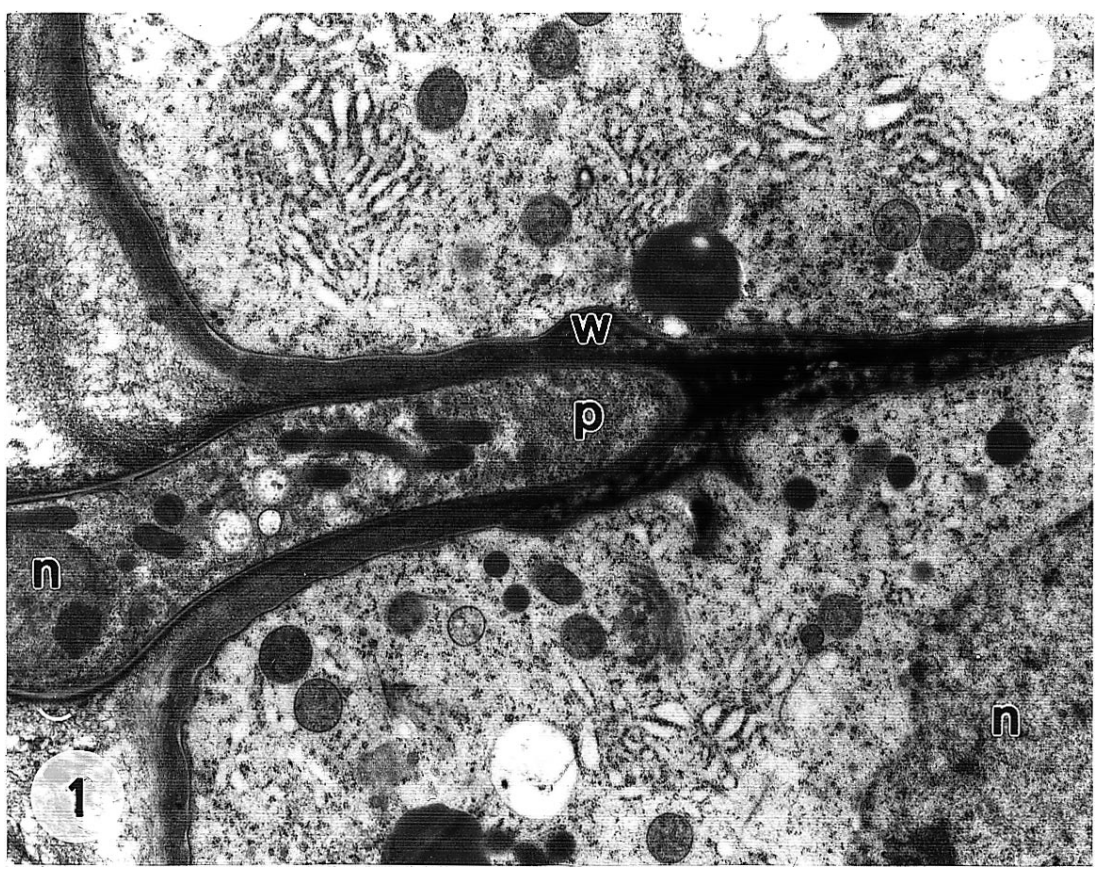

Figure 1 Direct penetration of the rhizodermis of Gossypium barbadense by Fusarium oxysorum ( $n=$ nucleus; $w=$ wall apposition produced by the host cell; $p=$ penetration hypha). Cross section of freeze substituted tissue $\times 11000$, courtesy E Rodriguez-Galvez, Piura, Peru.

oxysporum f. sp. vasinfectum produces a net-like mycelium on the surface of the root tip from which penetration hyphae develop. These hyphae penetrate epidermal walls directly and subsequently colonize the tissue by intra- and intercellular growth (Figure 1) (94). The wood rot fungus Phellinus noxis forms microhyphae that branch from running hyphae into host walls. The thin-walled microhyphae have an extracellular matrix (79), and highly localized degradation of cellulose was observed where this matrix extended into minute cracks of the cell wall (78). The smut fungus Ustilago maydis penetrates the cuticle with hyphae that exhibit only minor changes during penetration (100). Basidiospore germ tubes of rusts (Figure 2) are constricted to about one fifth of their diameter at the penetration site $(37,69)$. The border of the penetration pore is enforced by a wall structure, which forms a cone similar to that observed in fully differentiated appressoria.

The role of cutinase in penetration of the cuticle has recently been reviewed $(54,56,97)$. In Fusarium solani f. sp. pisi, dihydroxy- $\mathrm{C}_{16}$ and trihydroxy$\mathrm{C}_{18}$ fatty acids which are released from the cutin polymer by low levels of 
constitutively expressed cutinase, together with soluble nuclear protein factors were shown to activate cutinase gene transcription. Cyclic AMP and phosphorylation of transcription factors appear to be important in regulating cutinase gene expression (55). Initially, a large body of data indicated that cutinase of Fusarium plays an important role in penetration. Antibodies raised against cutinase were used in microscopical studies to substantiate that secretion occurs around the infection site, and both chemical cutinase inhibitors and antibodies decreased the rate of infection when present in the infection droplet. Furthermore, virulence correlated with levels of cutinase expression in different isolates. The cutinase gene of Fusarium solani f. sp. pisi was cloned and inserted into a cutinase-deficient isolate of the papaya wound pathogen $M y$ cosphaerella spp. Transformants expressing cutinase were able to infect papaya fruits through the intact cuticle. Antibodies against Fusarium solanif. sp. pisi cutinase prevented infection. These data were taken as strong evidence that cutinase is a determinant of virulence in Fusarium solani f. sp. pisi $(54,55)$.

The role of cutinase in penetration was questioned by Schäfer and co-workers, analyzing cutinase-deficient mutants of Fusarium solani f. sp. pisi generated

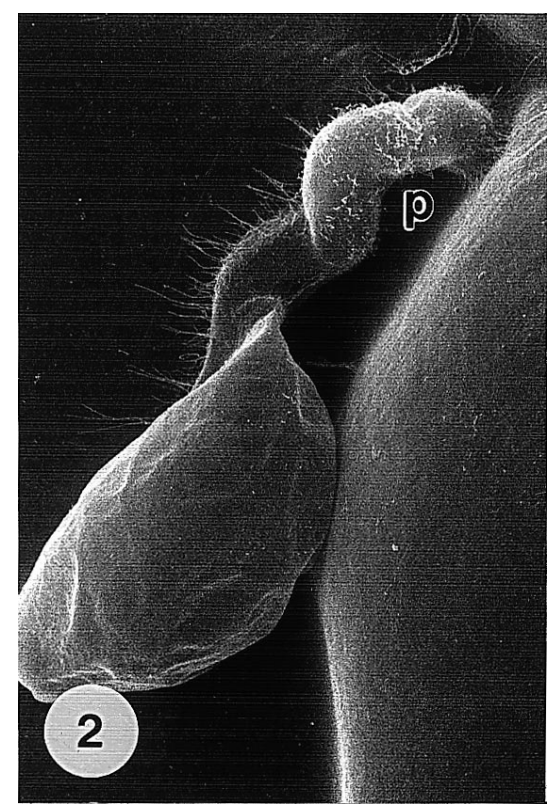

Figure 2 Direct penetration of the leaf cuticle by the basidiospore germling of Uromyces appendiculatus ( $p=$ penetration site). Scanning electron micrograph $\times 3100$, courtesy RE Gold, Limburgerhof, Germany. 
by transformation-mediated gene disruption (102). Detailed quantitative and microscopic examination of infection and the colonization process did not reveal any differences between wild-type and cutinase-deficient mutants and therefore gave no indication that cutinase is a virulence determinant in the $F$. solani $\mathrm{f}$. sp. pisi-pea interaction (103). Kolattukudy and co-workers used the mutant produced by Stahl \& Schäfer (102) and inoculated pea seedlings with a range of different spore concentrations (95). These authors, however, reported that virulence of the mutant was strongly decreased. One explanation for these conflicting data may be derived from the observation by Köller et al $(56,112 \mathrm{a})$ that distinct cutinases are expressed during saprophytic and pathogenic stages of Alternaria brassicicola. All Fusarium cutinases can be assumed to be inhibited by chemical inhibitors, and possibly also by the polyclonal antisera used in pea stem infection assays. However, targeted gene-disruption experiments may have inactivated only the cutinase gene active during saprophytic growth, but not the cutinase gene(s) required for pathogenicity. Further studies are required to clarify the different roles played by cutinases.

Directly penetrating fungi that do not differentiate appressoria clearly need cell wall-degrading enzymes for penetration. Localized degradation of plant cell wall material, about $0.2 \mu \mathrm{m}$ deep, was observed along the penetration hypha of $U$. vignae. In this area, the density of pectin and xyloglucan epitopes was reduced by about 50\% ( $\mathrm{H} \mathrm{Xu} \& \mathrm{~K}$ Mendgen, unpublished result). Culture fluids of isolates of Fusarium solani f. sp. pisi differing in virulence showed similar polygalacturonase activities, but polygalacturonate lyase activities correlated with virulence (53); a comparable situation was found in Fusarium oxysporum f. sp. lycopersici and Fusarium oxysporum f. sp. ciceri $(30,85)$. Antibodies against the lyase of Fusarium solani f. sp. pisi, but not those against the polygalacturonases, protected pea tissue against infection (38). Studies using UV- or chemically induced mutants of Fusarium, Verticillium, Sclerotinia, or Alternaria did not indicate a critical role played by pectic enzymes in pathogenesis (112). Also, after targeted disruption of a Penicillium olsonii gene encoding endo-polygalacturonase, mutants infected the host, Arabidopsis thaliana, at rates comparable to the wild type (61). However, since not all of the polygalacturonases had been inactivated in the mutants, no conclusion concerning their role can be drawn.

Elucidation of the importance of cell wall-degrading enzymes is hampered by their redundancy and variable regulation. Often, several isoforms of a particular enzyme occur that may be encoded by a single gene (13). In culture media containing purified plant cell walls or polymers such as pectin, polygalacturonic acid, cellulose, xylans, and others, many fungi synthesize an array of enzymes required to degrade these carbon sources. The presence of a single polymer such as polygalacturonic acid is often sufficient to induce a number of different enzymes, e.g. polygalacturonases, pectin and pectate (polygalacturonate) 
lyases, and pectin methylesterases. In plants, conserved promoter elements of defense-related genes responsive to pectic fragments have been identified (15). A similar situation may exist in fungi, such that plant cell wall fragments could activate fungal transcription factors capable of simultaneous induction of a number of genes encoding cell wall-degrading enzymes.

Whether enzymes produced in culture media are required for penetration of plant cell walls or only for saprophytic growth of the fungus is unresolved. For a better understanding of the role played by cell wall-degrading enzymes, the focus of research needs to be shifted toward those enzymes produced during pathogenesis, i.e. during penetration and growth in planta.

In the broad host range pathogen $B$. cinerea, pectin not only induces pectic enzymes (50), but also serves as a second inducer of laccase synthesis and secretion (66). Laccases are thought to contribute to degradation of lignin, a polymer incorporated into plant cell walls in response to pathogen attack (111). Since pectin can be esterified to phenolic compounds like ferulic acid and covalently linked with lignin (35), laccases may also be required for penetration (77). Importantly, specific inhibition of laccase by tetracyclic triterpenoids called cucurbitacins protected both cucumber fruits and cabbage leaves against infection by Botrytis cinerea (3).

\section{PENETRATION FROM FULLY DEVELOPED APPRESSORIA}

Many fungi such as Colletotrichum, Magnaporthe, Cochliobolus, or the dikaryon of rusts (Figure 3) form well-differentiated appressoria. Chemical signals such as potassium and calcium ions, simple sugars, acrolein, and $\mathrm{pH}$ gradients, as well as temperature shifts induce appressorium formation (44), but their significance is unclear. The major signals provided by the host are hydrophobicity $(49,64)$, hardness $(120)$, components of the plant surface (86), and topographical properties (44). Colletotrichum gloeosporioides and C. musae, which cause rot in climacteric fruits such as tomato, avocado, and banana, use the fruit-ripening hormone ethylene as a signal for germination and differentiation (31). Conidia of these fungi germinate and form multiple appressoria on glass surfaces after exposure to micromolar concentrations of ethylene gas. That ethylene emanating from ripening fruit is the actual signal was elegantly shown by using transgenic tomato fruits incapable of ethylene production. In contrast to normal tomato fruits, these transgenic fruits did not support fungal germination and appressorium differentiation unless exogenous ethylene was applied. In $C$. gloeosporioides (86), host surface wax components have also been shown to induce germination and appressorium differentiation. Recently, genes expressed during induction of appressorium formation in $C$. gloeosporioides by 


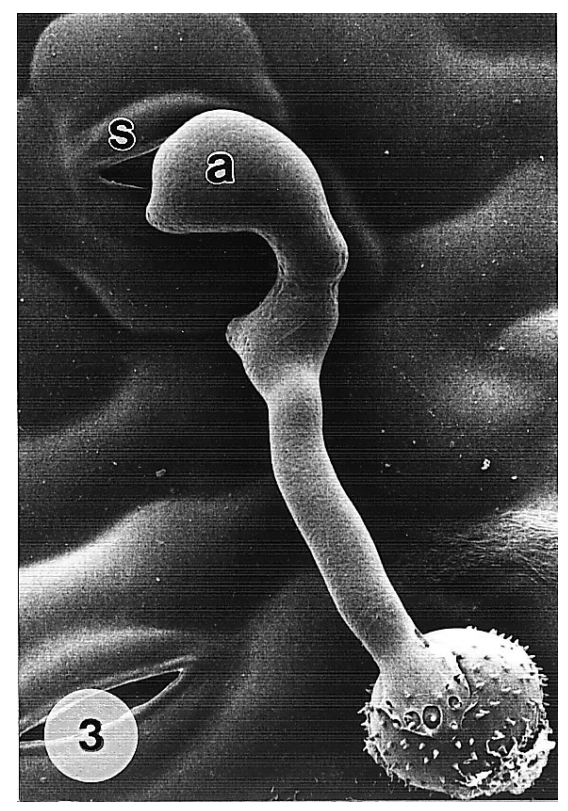

Figure 3 Penetration of the stomatal pore from an appressorium by the uredospore germling of $U$. appendiculatus ( $s=$ stoma, $a=$ appressorium). Low temperature scanning electron micrograph $\times 1000$.

the host surface wax have been cloned. Disruption of one of these genes, cap20, caused failure of the mutants to penetrate into the host tissue (48).

During different stages of its life cycle, the same fungus may respond to different signals provided by the same plant surface. Whereas the monokaryon of $U$. appendiculatus (Figure 2) differentiates infection structures in response to the hardness of the substrate (33), the dikaryon (Figure 3) differentiates appressoria in response to the correct dimensions of a ridge formed by the stomatal lips of the guard cell $(44,104)$. The signal for differentiation can be perceived in $U$. appendiculatus by the first $10 \mu \mathrm{m}$ of the hyphal tip (20). Within 4 min after signal perception, the cytoskeleton and the vesicles in the apex of the hypha are reorganized along the wall $(62,63)$. After the appressorial wall structure is completed, a new polarity emerges: Glycoproteins unique for the plasmalemma in the appressorium of $C$. lindemuthianum were detected only outside of the area of contact between the appressorium and the host cuticle, where the initials of the penetration hypha arise (82).

Fungi penetrating from fully developed appressoria show some variability with respect to melanization of the appressorial wall. For example, M. grisea 
and Colletotrichum spp. both incorporate a distinct melanin layer into their appressorial walls. Since only water but not osmotically active compounds can pass the plasma membrane and appressorial wall, a substantial pressure can be generated. A turgor pressure of $8.0 \mathrm{MPa}(80 \mathrm{bar}$ ) was measured in appressoria of $M$. grisea (47). This tugor pressure seems to be due to molar concentrations of glycerol in the appressoria of M. grisea (BJ McCormack \& NJ Talbot, unpublished result). Thus, even though these fungi are also capable of synthesizing cutinases and cell wall-degrading enzymes $(11,43,106,117)$, the data presented by Howard et al (47) suggest that fungi with melanized appressoria such as Magnaporthe and possibly Colletotrichum may be able to penetrate the host cuticle and cell wall mainly by means of turgor pressure. The essential role of melanin for penetration is supported by the observation that chemically induced melanin-deficient mutants are both unable to form melanized appressoria and are apathogenic $(17,57)$. Addition of appropriate precursors of melanin biosynthesis restored melanin incorporation into the appressorium and pathogenicity of the mutants. Correspondingly, after transformation of a mutant of $C$. lagenarium with wild-type DNA, transformants were obtained with melanized appressoria and normal virulence $(58,84 a)$. Microscopical investigations of melanin-deficient mutants of Magnaporthe and Colletotrichum revealed differences in the attempts to penetrate the host. While differentiation stopped in the mutant of $M$. grisea, the mutant of $C$. lagenarium formed lateral appressorial germ tubes and secondary appressoria (57). Lateral development may indicate that appressoria of Colletotrichum do not adhere as tightly to their substratum as those of Magnaporthe. The tight adhesion of Magnaporthe appressoria could be mediated by a ring of glue-like substances visible below the base of appressoria around the penetration pore (46). These substances may be similar to those found at conidial tips (40), or to extracellular glycoproteins thought to be involved in cellular differentiation (119).

\section{THE PENETRATION HYPHA}

Extensively studied examples for penetration hypha development are $C$. lindemuthianum (80), M. grisea (46), and rusts (68). The penetration hypha starts to grow from a pore in the middle of the appressorial base. The pore wall is very thin but often has reinforced borders. This reinforcement can turn into a thick wall structure, called the appressorial cone. Thus, pressure, generated by turgor and possibly also by the cytoskeleton, is exerted over the restricted area of the pore by the growing penetration hypha.

A pressure of $8 \mathrm{MPa}$ within the appressorium of $M$. grisea pushes the penetration hypha into artificial nonbiodegradable substrata such as Teflon (47). Assuming that the wall of the fungus offers no resistance to extension, the maximum force produced at the hyphal tip would be in the order of $8 \times 10^{-6} \mathrm{~N}(71)$. 
In contrast, appressoria of $U$. appendiculatus have a turgor pressure of only 0.35 MPa. Nevertheless, the base of this appressorium can distort polystyrene ridges, and the emerging penetration hypha can curl the stomatal lip inward (109).

The contribution of the cytoskeleton to these forces is unclear. Forces probably produced by actin and exerted on microneedles at the front of migrating keratocytes only reached a value of $6 \times 10^{-8} \mathrm{~N}(81)$, corresponding to a pressure of less than $0.002 \mathrm{MPa}$. These figures suggest that the force generated by the cytoskeleton is of some importance only if the turgor pressure is very low, as suggested for the water mold Saprolegnia when grown under osmotic stress (72). On the other hand, the high concentration of cytoskeletal elements observed in the penetration hyphae of $M$. grisea (8) and $U$. appendiculatus (121) may be necessary to determine the shape of this hypha. Even on the surface of scratched membranes, where no host cell wall restricts development of the fungus, penetration hyphae of Uromyces still keep their typical shape, indicating that it is controlled morphogenetically $(23,68)$. A stabilization of the tip of the penetration hypha would also be needed in fungi like $M$. grisea to compensate for the dramatic differences in osmotic pressure between appressorial and host cell protoplasts during the initial contact with the infected cell.

Compared to the tip of the germ tube, the wall of the penetration hypha has new features. In M. grisea (46), C. lindemuthianum (80), and several rusts (22, $34)$, the wall has strongly reduced affinity to wheat germ agglutinin, suggesting a reduced chitin content or a modification of chitin. In C. lagenarium and $U$. viciae-fabae, an increase in chitin deacetylase activity was observed after appressorium development (25, 99a, Figure 4). This enzyme activity probably modifies the chitin molecule on the surface of the penetration hypha. Since decreasing degrees of acetylation result in less efficient cleavage of chitin by endochitinases (91), the penetration hypha could be protected by enzymatic deacetylation. Furthermore, the amount of chitin degradation products, which may serve as elicitors of host defense reactions, would be reduced (22).

Penetration in the area of the appressorial pore is likely to be supported by enzymes that soften the host cell wall. At the beginning of development of the rust penetration hypha, apical vesicles start to accumulate over the penetration pore (105). In U. viciae-fabae, differentiation of appressorium and penetration hypha is accompanied by secretion of a complex pattern of lytic enzymes (Figure 4). With thigmo-inductive polyethylene membranes (23), enzyme formation during infection structure differentiation was analyzed in the absence of the plant. Thus, enzymes synthesized and secreted by the fungus can clearly be distiguished from cell wall polymer-degrading or -modifying enzymes formed by the plant at different stages of development (30a, 35a). During appressorium formation, several extracellular proteases appear that show specificity for fibrous hydroxyproline-rich proteins (88), reminiscent of structural 
plant proteins that are incorporated into the cell wall in response to fungal attack or elicitor treatment (99). In addition, several cellulolytic enzymes are formed, and a large proportion of the acidic isoforms were found extracellularly (42). When substomatal vesicles are differentiated, four pectin methylesterases are synthesized and secreted (21). Next, when haustorial mother cells develop and initiate host wall penetration, polygalacturonate lyase becomes detectable. Since no polygalacturonase was found, the lyase appears to be the only pectin depolymerizing enzyme. The lyase activity decreases drastically with increasing degrees of methylation of its substrate (H Deising, unpublished result), emphasizing the important role of pectin methylesterase. All of the cell walldegrading enzymes of $U$. viciae-fabae investigated are not subject to catabolite repression and do not require the presence of their substrate for induction, exept for the polygalacturonate lyase which, in addition to morphogenesis, needs the presence of polygalacturonate (21).

Interestingly, secretion of several cell wall-degrading enzymes does not necessarily result in extended tissue maceration, and this is especially true in the case of obligately biotrophic fungi (108). Destructive enzymes can be immobilized by ionic interaction with plant cell wall exchangers and by this means are restricted in their activity to local areas (5). Typically, this can be expected for many fungal polygalacturonate lyases, which have much more basic isoelectric points than the $\mathrm{pH}$ in the intercellular space and the plant cell wall. Thus,

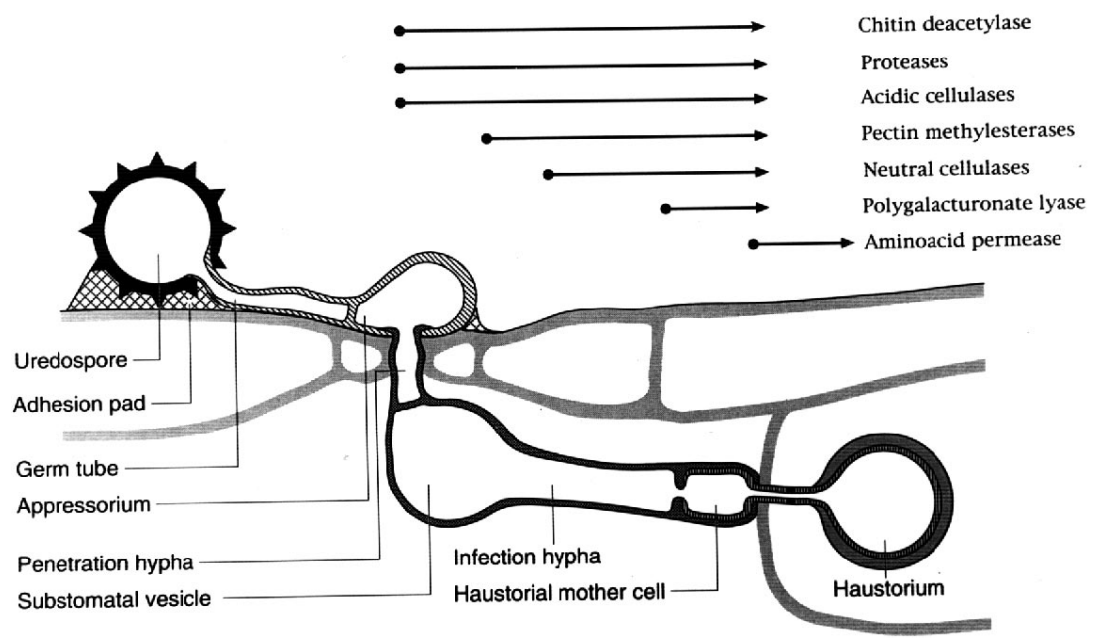

Figure 4 Concerted differentiation of infection structures and production of enzymes by Uromyces viciae-fabae. Note that some cell wall-degrading enzymes are already produced during stomatal penetration. A putative amino acid permease was identified that is specifically expressed in haustoria (M Hahn and K Mendgen unpublished). 
physicochemical properties of these enzymes are likely to determine the degree of cell or tissue damage (21).

In C. gloeosporioides, evidence for the role of cell wall-degrading enzymes during the penetration process has been obtained by Prusky and coworkers (114). Both pectin-degrading enzymes and penetration of fruit tissue are inhibited by epicatechin, a phenolic compound present in the peel of unripe avocado fruits. During ripening, levels of epicatechin decrease to a threshold not inhibitory to the pectic enzymes, and the fungus gains the ability to spread within the fruit.

Cochliobolus spp. form only weakly melanized appressoria (113), and melanin-deficient mutants of the rice pathogen $C$. miyabeanus remain infectious (59). On the other hand, Cochliobolus species produce a large number of cell wall-degrading enzymes that might play an important role in the penetration process. To test this hypothesis, Walton and co-workers performed targeted inactivation of genes of $C$. carbonum encoding cell wall-degrading enzymes such as endo-polygalacturonase, xylanase, $\beta$-1,3-glucanase, and cellulase (2, $96,98,101)$. Likewise, in the apple fruit pathogen Glomerella cingulata, a gene coding for a pectin lyase was inactivated (9). In neither case was the virulence of the resulting mutants affected. However, all mutants retained various degrees of residual enzyme activity, probably due to genes encoding isoforms of the respective enzyme, which were not affected by mutagenesis. Thus, based on the data currently available, no general conclusion can be drawn concerning the role played by fungal cell wall-degrading enzymes in the penetration process.

\section{CONCLUDING REMARKS}

Research over the past few years has significantly increased our knowledge of penetration by plant pathogenic fungi, unfolding a process of unexpected complexity. The diversity of fungal penetration strategies as well as the many tools needed by a particular pathogen to successfully enter its host make generalizations difficult.

The ability to construct defined single-gene disruption mutants in a number of phytopathogenic fungi has so far given clear-cut answers only in a few cases, such as the role of melanin in the formation of functional appressoria. The particular role of cutinase and of cell wall-degrading enzymes is still unresolved, due to the redundancy of the encoding genes. Functional redundancy is often indicative of processes with vital importance to an organism. Numerous enzymes, sometimes with overlapping activities, are needed to degrade the complex web of carbohydrates, glycoproteins, and phenolic compounds of the plant cell wall. This might explain the difficulty in detecting the effect of a single enzyme in the combination of activities involved in cell wall degradation. 
There is an interesting parallel in the bacterial soft rotting Erwinia spp., in which the cell wall-degrading enzymes are encoded by several gene families (4). Disruption of single genes never completely abolished pathogenicity, and in many cases no effect on virulence could be observed. Even the deletion of all known pectate lyase genes did not eliminate macerating ability because of the presence of newly detected pectate lyase genes that were only expressed in planta $(1,4)$. These observations are similar to those obtained by Köller et al (56) with cutinases from Alternaria and suggest similar molecular strategies of bacterial and fungal plant pathogens.

Transformation and targeted gene disruption mutagenesis remains a laborious and time-consuming task for most of the phytopathogenic fungi, and there is still no effective way to stably transform the biotrophic fungi. Therefore, we cannot expect rapid progress in elucidating the mechanisms of cell wall penetration, except for some model systems such as $C$. carbonum (112).

Instead of altering the ability of a particular fungal pathogen to produce cell wall-degrading enzymes and to analyze the resulting phenotypes, work with genetically altered host plants offers a promising alternative. For example, in transgenic tomatoes, high-level expression of pear polygalacturonase inhibitory proteins (PGIPs) led to increased resistance of the fruits to $B$. cinerea, providing indirect evidence that polygalacturonase might be a virulence factor in this fungus (87). Mutants defective in certain cell wall carbohydrates have been obtained from Arabidopsis (90), and these mutants can be tested for an altered susceptibility to Arabidopsis pathogens.

Because of the limitations of approaches toward known enzymatic activities, molecular genetic techniques that do not require a priori knowledge of the pathosystem are increasingly used by plant pathologists. These techniques include the search for genes specifically expressed during penetration and subsequent analysis of their mutant phenotypes (48), as well as random insertion mutagenesis (e.g. REMI) followed by screening for mutants defective in pathogenicity (6). The great promise of these "black box" approaches is that they will provide insight into the molecular mechanisms of penetration that are still obscure.

With modern molecular techniques, it now seems possible to uncover the cascade of signaling events between and within the fungal parasite and its host plant during penetration. Identification of plant-derived signals and parts of the signal transduction chains involved in cutinase induction in F. solani and appressorium formation in C. gloeosporioides and $M$. grisea illustrate these developments. On the other hand, our knowledge of molecular and cytological events inside and surrounding the invading fungus is limited. We still do not understand the mechanism of highly specific, pathogen-induced responses of host plants, for example, the formation of a unique type of plasma membrane 
(the extrahaustorial membrane) that surrounds haustoria of biotrophic fungi and apparently supports their nutrition. So far, cytological techniques have mainly been used for a descriptive view of fungal pathogenesis, but with the help of molecular biology, electron microscopy can be used to locate specific molecules at the penetration site. Careful cytological investigations will also be indispensable for the analysis of gene disruption mutants that do not reveal a phenotype by macroscopic evaluation. During penetration, the decision is often made whether or not a pathogen will succeed in colonizing the plant. We are still far from understanding all the factors determining the outcome of this battle, and therefore the initial phase of fungal infection remains a subject of great scientific and practical interest.

\section{ACKNOWLEDGMENTS}

We thank RL Nicholson, HC Hoch, NP Money, and M Rauscher for helpful comments on the manuscript, and the Deutsche Forschungsgemeinschaft for financial support.

\section{Literature Cited}

1. Alghisi P, Favaron F. 1995. Pectindegrading enzymes and plant-parasite interactions. Eur. J. Plant Pathol. 101:365-75

2. Apel PC, Panaccione DG, Holden FR, Walton JD. 1993. Cloning and targeted gene disruption of $X Y L 1$, a $\beta 1,4-$ xylanase gene from the maize pathogen Cochliobolus carbonum. Mol. PlantMicrobe Interact. 6:467-73

3. Bar-Nun N, Mayer AM. 1990. Cucurbitacins protect cucumber tissue against infection by Botrytis cinerea. Phytochemistry 29:787-91

4. Barras F, von Gijsegem F, Chatterjee AK. 1994. Extracellular enzymes and pathogenesis of soft-rot Erwinia. Annu. Rev. Phytopathol. 32:201-34

5. Benhamou N, Chamberland H, Pauzé FJ. 1990. Implication of pectic components in cell surface interactions between tomato root cells and Fusarium oxysporum f. sp. radicis-lycopersici. Plant Physiol. 92:995-1003

6. Bölker M, Böhnert HU, Braun $\mathrm{KH}$, Görl J, Kahmann R. 1995. Tagging pathogenicity genes in Ustilago maydis by restriction enzyme-mediated integration (REMI). Mol. Gen. Genet. 248: 547-52

7. Bonfante P, Perotto S. 1995. Strategies of arbuscular mycorrhizal fungi when in- fecting host plants. New Phytol. 130:321

8. Bourett TM, Howard RJ. 1992. Actin in penetration pegs of the fungal rice blast pathogen, Magnaporthe grisea. Protoplasma 168:20-26

9. Bowen JK, Templeton MD, Sharrock KR, Crowhurst RN, Rikkerink EHA. 1995. Gene inactivation in the plant pathogen Glomerella cingulata: three strategies for the disruption of the pectin lyase gene pnlA. Mol. Gen. Genet. 246:196-205

10. Braun EJ, Howard RJ. 1994. Adhesion of Cochliobolus heterostrophus conidia and germlings to leaves and artificial surfaces. Exp. Mycol. 18:211-20

11. Bucheli P, Doares SH, Albersheim P, Darvill A. 1990. Host-pathogen interactions XXXVI. Partial purification and characterization of heat-labile molecules secreted by the rice blast pathogen that solubilize plant cell wall fragments that kill plant cells. Physiol. Mol. Plant Pathol. 36:159-73

12. Cairney JWG, Bruke RM. 1994. Fungal enzymes degrading plant cell walls: their possible significance in the ectomycorrhizal symbiosis. Mycol. Res. 98:1345-56

13. Caprari C, Bergmann C, Migheli Q, Salvi G, Albersheim P, Darvill A, Cer- 
vone F, De Lorenzo G. 1993. Fusarium moniliforme secretes four endopolygalacturonases derived from a single gene product. Physiol. Mol. Plant Pathol. 43:453-62

14. Carver TLW, Ingerson-Morris SM, Thomas BJ, Zeyen RJ. 1995. Early interactions during powdery mildew infection. Can. J. Bot. 73:S632-39

15. Cervone F, De Lorenzo G, Caprari C, Clark AJ, Desiderio A, et al. 1993. The interaction between fungal endopolygalacturonase and plant cell wall PGIP (polygalacturonase-inhibiting protein). In Mechanisms of Plant Defense Responses, ed. B Fritig, M Legrand, pp. 64-7. Dordrecht: Kluwer

16. Chaubal R, Wilmot VA, Wynn WK. 1991. Visualization, adhesiveness and cytochemistry of the extracellular matrix produced by germ tubes of $P$ uccinia sorghi. Can. J. Bot. 69:2044-54

17. Chumley FG, Valent B. 1990. Genetic analysis of melanin-deficient, nonpathogenic mutants of Magnaporthe grisea. Mol. Plant-Microbe Interact. 3:135-43

18. Clay RP, Enkerli J, Fuller MS. 1994. Induction and formation of Cochliobolus sativus appressoria. Protoplasma 178: 34-47

19. Clement JA, Porter R, Butt TM, Beckett A. 1994. The role of hydrophobicity in attachment of urediniospores and sporelings of Uromyces viciae-fabae. Mycol. Res. 98:1217-28

19a. Cole GT, Hoch HC, eds. 1991. The Fungal Spore and Disease Initiation in Plants and Animals. New York: Plenum. $555 \mathrm{pp}$.

19b. Cole L, Dewey F M, Hawes C R. 1996. Infection mechanisms of Botrytis species: pre-penetration and preinfection processes of dry and wet conidia. Mycol. Res. 100:277-86

20. Correa AJ, Hoch HC. 1995. Identification of thigmoresponsive loci for cell differentiation in Uromyces germlings. Protoplasma 186:34-40

21. Deising H, Frittrang AK, Kunz S, Mendgen K. 1995. Regulation of pectin methylesterase and polygalacturonate lyase activity during differentiation of infection structures in Uromyces viciaefabae. Microbiology 141:561-71

22. Deising H, Heiler S, Rauscher M, Xu H, Mendgen K. 1996. Cellular aspects of rust infection structure differentiation: spore adhesion and fungal morphogenesis. See Ref. 79a, pp. 135-56
23. Deising H, Jungblut PR, Mendgen K. 1991. Differentiation-related proteins of the broad bean rust fungus Uromyces viciae-fabae, as revealed by high resolution two-dimensional polyacrylamide gel electrophoresis. Arch. Microbiol. 155:191-98

24. Deising H, Nicholson RL, Haug M, Howard RJ, Mendgen K. 1992. Adhesion pad formation and the involvement of cutinase and esterases in the attachment of uredospores to the host cuticle. Plant Cell 4:1101-11

25. Deising H, Siegrist J. 1995. Chitin deacetylase activity of the rust Uromyces viciae-fabae is controlled by fungal morphogenesis. FEMS Microbiol. Lett. 127:207-12

26. Dixon DM, Szanislo PJ, Polak A. 1991. Dihydroxynaphthalene melanin and its relationship with virulence in the early stages of Phaeohyphomycosis. See Ref. 19a, pp. 297-318

27. Doss RP, Potter SW, Chastagner GA, Christian JK. 1993. Adhesion of nongerminated Botrytis cinerea conidia to several substrata. Appl. Environ. Microbiol. 59:1786-91

28. Doss RP, Potter SW, Soeldner AH, Christian JK, Fukunaga LE. 1995. Adhesion of germlings of Botrytis cinerea. Appl. Environ. Microbiol. 61:260-5

29. Epstein L, Laccetti LB, Staples RC, Hoch HC. 1987. Cell-substratum adhesive protein involved in surface contact responses of the bean rust fungus. Physiol. Mol. Plant Pathol. 30:373-88

30. Fernández N, Patiño B, Vázquez C. 1993. Pectin degrading enzymes secreted by six isolates of Fusarium oxysporum. Mycol. Res. 97:461-66

30a. Fischer RL, Bennett AB. 1991. Role of cell wall hydrolases in fruit ripening. Annu. Rev. Plant Physiol. Plant Mol. Biol. 42:675-703

31. Flaishman MA, Kolattukudy PE. 1994. Timing of fungal invasion using host's ripening hormone as a signal. Proc. Natl. Acad. Sci. USA 91:6579-83

32. Förster H, Mendgen K. 1987. Immunocytochemical localization of pectinesterases in hyphae of Phytophthora infestans. Can. J. Bot. 65:2607-13

33. Freytag S, Bruscaglioni L, Gold RE, Mendgen K. 1988. Basidiospores of rust fungi (Uromyces species) differentiate infection structures in vitro. Exp. Mycol. $12: 275-83$

34. Freytag S, Mendgen K. 1991. Carbohy- 
drates on the surface of urediniosporeand basidiospore-derived infection structures of heteroecious and autoecious rust fungi. New Phytol. 119:527-34

35. Fry SC. 1986. Cross-linking of matrix polymers in the growing cell walls of angiosperms. Annu. Rev. Plant Physiol. 37:165-86

35a. Fry SC. 1995. Polysaccharide-modifying enzymes in the plant cell wall. Annu. Rev. Plant Physiol. Plant Mol. Biol. 46: 497-520

36. Girbardt M. 1957. Der Spitzenkörper von Polystictus versicolor. Planta 50:47-59

37. Gold RE, Mendgen K. 1991. Rust basidiospore germlings and disease initiation. See Ref. 19a, pp. 67-99

38. González-Candelas L, Kolattukudy PE. 1992. Isolation and analysis of a novel inducible pectate lyase gene from the phytopathogenic fungus Fusarium solani f. sp. pisi (Nectria haematococca, mating population VI). J. Bacteriol. 174:6343-49

39. Gow NAR. 1994. Growth and guidance of the fungal hypha. Microbiology 140:3193-205

40. Hamer JE, Howard RJ, Chumley FG, Valent B. 1988. A mechanism for attachment in spores of a plant pathogenic fungus. Science 239:288-90

41. Heath IB. 1994. The cytoskeleton in hyphal growth, organelle movements, and mitosis. In The Mycota I, ed. J Wessels, F Meinhardt, pp. 43-65. Heidelberg: Springer

42. Heiler S, Mendgen K, Deising H. 1993. Cellulolytic enzymes of the obligately biotrophic rust fungus Uromyces viciaefabae are regulated differentiationspecifically. Mycol. Res. 97:77-85

43. Hirayama T, Sudo T, Nagayama H, Matsuda K, Tamari K. 1976. Number and interrelation of components of $\mathrm{C}_{\mathrm{X}}$ enzyme from Pyricularia oryzae. Agric. Biol. Chem. 40:2137-42

44. Hoch HC, Staples RC. 1991. Signaling for infection structure formation in fungi. See Ref. 19a, pp. 25-46

45. Hoch HC, Staples RC. 1987. Structural and chemical changes among the rust fungi during appressorium development. Annu. Rev. Phytopathol. 25:23147

46. Howard RJ, Bourett TM, Ferrari MA. 1991. Infection by Magnaporthe: an in vitro analysis. See Ref. 68a, pp. 251-64

47. Howard RJ, Ferrari MA, Roach DH,
Money NP. 1991. Penetration of hard substrates by a fungus employing enormous turgor pressures. Proc. Natl. Acad. Sci. USA 88:11281-84

48. Hwang C-S, Flaishman MA, Kolattukudy PE. 1995. Cloning of a gene expressed during appressorium formation by Colletotrichum gloeosporioides and a marked decrease in virulence by disruption of this gene. Plant Cell 7:18393

49. Jelitto TC, Page HA, Read ND. 1994. Role of external signals in regulating the pre-penetration phase of infection by the rice blast fungus, Magnaporthe grisea. Planta 194:471-77

50. Johnston DJ, Williamson B. 1992. Purification and characterization of four polygalacturonases from Botrytis cinerea. Mycol. Res. 96:343-49

51. Jones EBG. 1994. Fungal adhesion. $M y$ col. Res. 98:961-81

52. Klis FM. 1994. Protein secretion in yeast. In The Mycota I, ed. J Wessels, F Meinhardt, pp. 25-41. Heidelberg: Springer

53. Kolattukudy PE, Crawford MS. 1987. The role of polymer degrading enzymes in fungal pathogenesis. In Molecular Determinants of Plant Diseases, ed. S Nishimura, VP Vance, N Doke, pp. 7595. Heidelberg/Tokyo: Springer

54. Kolattukudy PE, Kämper J, Kämper U, González-Candelás L, Guo W. 1994. Fungus-induced degradation and reinforcement of defensive barriers of plants. See Ref. 85a, pp. 67-79

55. Kolattukudy PE, Rogers LM, Li D, Hwang C-S, Flaishman MA. 1995. Surface signaling in pathogenesis. Proc. Natl. Acad. Sci. USA 92:4080-87

56. Köller W, Yao C, Trail F, Parker DM. 1995. Role of cutinase in the invasion of plants. Can. J. Bot. 73:S1109-18

57. Kubo Y, Furusawa I. 1991. Melanin biosynthesis. Prerequisite for successful invasion of the host by appressoria of Colletotrichum and Pyricularia. See Ref. 19a, pp. 205-18

58. Kubo Y, Nakamura H, Kobayashi K, Okuno T, Furusawa I. 1991. Cloning of a melanin biosynthetic gene essential for appressorial penetration of Colletotrichum lagenarium. Mol. PlantMicrobe Interact. 4:440-45

59. Kubo Y, Tsuda M, Furusawa I, Shishiyama J. 1989. Genetic analysis of genes involved in melanin biosynthesis of Cochliobolus miyabeanus. Exp. Mycol. 13:77-84 
60. Kunoh H, Nicholson RL, Yoshioka H, Yamaoka N, Kobayashi I. 1990. Preparation of the infection court by Erysiphe graminis: degradation of the host cuticle. Physiol. Mol. Plant Pathol. 36:397407

61. Kusserow H, Schaäfer W. 1994. The role of polygalacturonase in the interaction between Penicillium olsonii and Arabidopsis thaliana. Abstr. 442. 7th Int. Symp. Mol. Plant Micobe Interact., Edinburgh

62. Kwon YH, Hoch HC, Aist JR. 1991. Initiation of appressorium formation in Uromyces appendiculatus: organization of the apex, and the responses involving microtubules and apical vesicles. Can.J. Bot. 69:2560-73

63. Kwon YH, Hoch HC, Staples RC. 1991. Cytoskeletal organization in Uromyces urediospore germlings apices during appressorium formation. Protoplasma 165:37-50

63a. Kwon YH, Epstein L. 1993. A 90 kDa glycoprotein associated with adhesion of Nectria haematococca macroconidia to substrata. Mol. Plant Microbe Interact. 6:481-87

64. Lee Y-H, Dean RA. 1993. cAMP regulates infection structure formation in the plant pathogenic fungus Magnaporthe grisea. Plant Cell 5:693-700

65. López-Franco R, Howard RJ, Bracker CE. 1995. Satellite Spitzenkörper in growing hyphal tips. Protoplasma 188:85-103

66. Marbach I, Harel E, Mayer AM. 1985. Pectin, a second inducer for laccase production by Botrytis cinerea. Phytochemistry 24:2559-61

67. Mendgen K, Bachem U, Stark-Urnau M, $\mathrm{Xu} \mathrm{H}$. 1995. Secretion and endocytosis at the interface of plants and fungi. Can. J. Bot. 73:S640-48

68. Mendgen K, Deising H. 1993. Infection structures of fungal plant pathogensa cytological and physiological evaluation. New Phytol. 124:193-213

68a. Mendgen K, Lesemann D-E, eds. 1991. Electron Microscopy of Plant Pathogens. Berlin: Springer. 336 pp.

69. Mims CW. 1991. Using electron microscopy to study plant pathogenic fungi. Mycologia 83:1-19

70. Moloshok TD, Leinhos GME, Staples RC, Hoch HC. 1993. The autogenic extracellular environment of Uromyces appendiculatus urediospore germlings. Mycologia 85:392-400

71. Money NP. 1995. Turgor pressure and the mechanics of fungal penetration. Can. J. Bot. 73:S96-102

72. Money NP, Harold FM. 1993. Two water molds can grow without measurable tugor pressure. Planta 190:426-30

73. Nicholson RL. 1996. Adhesion of fungal propagules. See Ref. 79a, pp. 117-34

74. Nicholson RL, Epstein L. 1991. Adhesion of fungi to the plant surface: prerequisite for pathogenesis. See Ref. 19a, pp. 3-23

75. Nicholson RL, Kunoh H, Shiraishi T, Yamada T. 1993. Initiation of the infection process by Erysiphe graminis: conversion of the conidial surface from hydrophobicity to hydrophilicity and influence of the conidial exudate on the hydrophobicity of the barley leaf surface. Physiol. Mol. Plant Pathol. 43:30718

76. Nicholson RL, Yoshioka H, Yamaoka N, Kunoh H. 1988. Preparation of the infection court by Erysiphe graminis. II. Release of esterase enzyme from conidia in response to a contact stimulus. Exp. Mycol. 12:336-49

77. Nicole M, Chamberland H, Geiger JP, Lecours N, Valéro J, et al. 1992. Immunocytochemical localization of laccase in wood decayed by Rigidoporus lignosus. Appl. Environ. Microbiol. 58:1727-39

78. Nicole M, Chamberland H, Rioux D, Lecours N, Rio B, et al. 1993. A cytochemical study of extracellular sheaths associated with Rigidiporus lignosus during wood decay. Appl. Environ. Microbiol. 59:2578-88

79. Nicole M, Chamberland H, Rioux D, Xixuan X, Blanchettte RA, et al. 1995. Wood degradation by Phellinus noxius: ultrastructure and cytochemistry. Can.J. Microbiol. 41:253-65

79a. Nicole M, Gianinazzi-Pearson V, eds. 1996. Histology, Ultrastructure and Molecular Cytology of Plant-Microorganism Interactions. Dordrecht: Kluwer. 261 pp.

80. O'Connell RJ, Bailey JA. 1991. Hemibiotrophy in Colletotrichum lindemuthianum. See ref. 68a, pp. 211-22

80a. O'Connell RJ, Pain NA, Hutchinson KA, Jones GL, Green JR. 1996. Ultrastructure and composition of the cell surfaces of infection structures formed by the fungal plant pathogen Colletotrichum lindemuthianum. J. Microscopy 181:204-12

81. Oliver T, Lee J, Jacobson K. 1994. 
Forces exerted by locomoting cells. Semin. Cell Biol. 5:139-47

82. Pain NA, O'Connell RJ, Green JR. 1995. A plasma membrane-associated protein is a marker for differentiation and polarisation of Colletotrichum lindemuthianum appressoria. Protoplasma 127:233-42

83. Pascholati SF, Deising H, Leite B, Anderson D, Nicholson RL. 1993. Cutinase and non-specific esterase activities in the conidial mucilage of Colletotrichum graminicola. Physiol. Mol. Plant Pathol. 42:37-51

84. Pascholati SF, Yoshioka H, Kunoh H, Nicholson RL. 1992. Preparation of the infection court by Erysiphe graminis $\mathrm{f}$. sp. hordei: cutinase is a component of the conidial exudate. Physiol. Mol. Plant Pathol. 41:53-59

84a. Perpetua NS, Kubo Y, Okuno T, Furusawa I. 1994. Restoration of pathogenicity of a penetration-deficient mutant of Colletotrichum lagenarium by DNA complementation. Curr. Genet. 25:4146

85. Pérez-Artés E, Tena M. 1990. Purification and characterization of pectic enzymes from two races of Fusarium oxysporum f.sp. ciceri differing in virulence to chickpea (Cicer arietinum L.). Physiol. Mol. Plant Pathol. 37:107-24

85a. Petrini O, Ouellette GB, eds. 1994. Host Wall Alterations by Parasitic Fungi. St. Paul: APS. 159 pp.

86. Podila GK, Rogers LM, Kolattukudy PE. 1993. Chemical signals from avocado surface wax trigger germination and appressorium formation in Colletotrichum gloeosporioides. Plant Physiol. 103:267-72

87. Powell ALT, D'hallewin G, Hall BD, Stotz H, Labavitch JM, Bennett AB. 1994. Glycoprotein inhibitors of fungal polygalacturonases: expression of pear PGIP improves resistance in transgenic tomatoes. Plant Physiol. 105:159

88. Rauscher M, Mendgen K, Deising $\mathrm{H}$. 1995. Extracellular protease of the rust fungus Uromyces viciae-fabae. Exp. Mycol. 19:26-34

89. Read ND, Kellock LJ, Knight H, Trewavas AJ. 1992. Contact sensing during infection by fungal pathogens. In Perspectives in Plant Cell Recognition, ed. JA Callow, JR Green, 48:137-72. Cambridge: Cambridge Univ. Press

90. Reiter W-D. 1994. The use of Arabidopsis genetics to analyze synthesis, structure, and function of the plant cell wall.
In Plant Molecular Biology. Molecular Genetic Analysis of Plant Development and Metabolism, ed. G Coruzzi, P Puigdomènech, pp. 117-27. NATO ASI Ser. Berlin: Springer

91. Ride JP, Barber MS. 1990. Purification and characterization of multiple forms of endochitinase from wheat leaves. Plant Sci. 71:185-97

92. Rijkenberg FHJ, De Leeuw GTN, Verhoeff K. 1980. Light and electron microscopy studies on the infection of tomato fruits by Botrytis cinerea. Can. J. Bot. 58:1394-404

93. Roberson RW, Vargas MM. 1994. The tubulin cytoskeleton and its sites of nucleation in hyphal tips of Allomyces macrogynus. Protoplasma 182:19-31

94. Rodríguez-Gálvez E, Mendgen K. 1995. The infection process of Fusarium oxysporum in cotton root tips. Protoplasma 189:61-72

95. Rogers LM, Flaishman MA, Kolattukudy PE. 1994. Cutinase gene disruption in Fusarium solani f sp pisi decreases its virulence on pea. Plant Cell 6:935-45

96. Schaeffer HJ, Leykam J, Walton JD. 1994. Cloning and targeted gene disruption of $E X G 1$, encoding exo- $\beta-1,3$ glucanase, in the phytopathogenic fungus Cochliobolus carbonum. Appl. Environ. Microbiol. 60:594-98

97. Schäfer W. 1994. Molecular mechanisms of fungal pathogenicity to plants. Annu. Rev. Phytopathol. 32:461-77

98. Scott-Craig JS, Panaccione DG, Cervone F, Walton JD. 1990. Endopolygalacturonase is not required for pathogenicity of Cochliobolus carbonum on maize. Plant Cell 2:1191-200

99. Sheng J, Showalter AM. 1994. Plant cell wall structural proteins: regulated expression and roles in fungal infection. See Ref. 85a, pp. 91-102

99a. Siegrist J, Kauss H. 1990. Chitin deacetylase in cucumber leaves infected by Colletotrichum lagenarium. Physiol. Mol. Plant Pathol. 36:267-75

100. Snetselaar KM, Mims CW. 1994. Light and electron microscopy of Ustilago maydis hyphae. Mycol. Res. 98:34755

101. Sposato P, Ahn J-H, Walton JD. 1995. Characterization and disruption of a gene in the maize pathogen Cochliobolus carbonum encoding a cellulase lacking a cellulose binding domain and hinge region. Mol. Plant-Microbe Interact. 8:602-9 
102. Stahl DJ, Schäfer W. 1992. Cutinase is not required for fungal pathogenicity on pea. Plant Cell 4:621-29

103. Stahl DJ, Theuerkauf A, Heitefuss R, Schäfer W. 1994. Cutinase of Nectria haematococca (Fusarium solani f. sp. pisi) is not required for fungal virulence or organ specificity on pea. Mol. PlantMicrobe Interact. 7:713-25

104. Stark-Urnau M, Mendgen K. 1993. Differentiation of aecidiospore- and uredospore-derived infection structures on cowpea leaves and on artificial surfaces by Uromyces vignae. Can. J. Bot. 71:1236-42

105. Swann EC, Mims CW. 1991. Ultrastructure of freeze-substituted appressoria produced by aeciospore germlings of the rust fungus Arthuriomyces peckianus. Can. J. Bot. 69:1655-65

106. Sweigard JA, Chumley FG, Valent B. 1992. Disruption of a Magnaporthe grisea cutinase gene. Mol. Gen. Genet. 232:183-90

107. Talbot NJ, Ebbole DJ, Hamer JE. 1993. Identification and characterisation of $M p g 1$, a gene involved in pathogenicity from the rice blast fungus Magnaporthe grisea. Plant Cell 5:1575-90

108. Taylor J, Mims CW. 1991. Fungal development and host cell responses to the rust fungus Puccinia substriata var. indica in seedlings and mature leaves of susceptible and resistant pearl millet. Can. J. Bot. 69:1207-19

109. Terhune BT, Bojko RJ, Hoch HC. 1993. Deformation of stomatal guard cell lips and microfabricated artificial topographies during appressorium formation by Uromyces. Exp. Mycol. 17:7078

110. Terhune BT, Hoch HC. 1993. Substrate hydrophobicity and adhesion of Uromyces urediospores and germlings. Exp. Mycol. 17:241-52

110a. Van den Ackerveken GFJM, Dunn RM, Cozijnsen AJ, Vossen JPMJ, Van den Broek HWJ, De Wit PGM. 1994. Nitrogen limitation induces expression of the avirulence gene $a v r 9$ in the tomato pathogen Cladosporium fulvum. Mol. Gen. Genet. 243:277-85

111. Viterbo A, Staples RC, Yagen B, Mayer AM. 1994. Selective mode of action of cucurbitacin in the inhibition of laccase formation in Botrytis cinerea. Phytochemistry 35:1137-42

112. Walton JD. 1994. Deconstructing the cell wall. Plant Physiol. 104:1113-18

113. Walton JD, Bronson CR, Panaccione
DG, Braun EJ, Akimitsu K. 1995. Cochliobolus. In Pathogenesis and Host Specificity in Plant Diseases. Histopathological, Biochemical, Genetic and Molecular Bases. Eukaryotes, ed. K Kohmoto, US Singh, RP Singh, 2:65-81. Oxford: Elsevier

114. Wattad C, Dinoor A, Prusky D. 1994. Purification of pectate lyase produced by Colletotrichum gloeosporioides and its inhibition by epicatechin: a possible factor involved in the resistance of unripe avocado fruits to anthracnose. Mol. Plant-Microbe Interact. 7:293-97

115. Wessels JGH. 1994. Developmental regulation of fungal cell wall formation. Annu. Rev. Phytopathol. 32:439-59

116. Wessels JGH. 1993. Wall growth, protein excretion and morphogenesis in fungi. New Phytol. 123:397-413

117. Wijesundera RLC, Bailey JA, Byrde RJW, Fielding AH. 1989. Cell wall degrading enzymes of Colletotrichum lindemuthianum: their role in the development of bean anthracnose. Physiol. Mol. Plant Pathol. 34:403-13

118. Wösten HAB, Schuren FHJ, Wessels JGH. 1994. Interfacial self-assembly of a hydrophobin into an amphipathic protein membrane mediates fungal attachment to hydrophobic surfaces. EMBO J. 13:5848-54

119. Xiao J-Z, Ohshima A, Kamakura T, Ishiyama T, Yamaguchi I. 1994. Extracellular glycoprotein(s) associated with cellular differentiation in Magnaporthe grisea. Mol. Plant-Microbe Interact. 7:639-44

120. Xiao JZ, Ohshima A, Watanabe T, Kamakura T, Yamaguchi I. 1994. Studies on cellular differentiation of Magnaporthe grisea. Physico-chemical aspects of substratum surfaces in relation to appressorium formation. Physiol. Mol. Plant Pathol. 44:227-36

121. Xu H, Mendgen K. 1994. Endocytosis of $1,3-\beta$-glucans by broad bean cells at the penetration site of the cowpea rust (haploid stage). Planta 195:282-90

121a. Yao C, Köller W. 1995. Diversity of cutinases from plant pathogenic fungi: Different cutinases are expressed during saprophytic and pathogenic stages of Alternaria brassicicola. Mol. PlantMicrobe Interact. 8:122-30

122. Zhou XL, Stumpf MA, Hoch HC, Kung C. 1991. A mechano-sensitive cation channel in the plasma membrane of the topography sensing fungus Uromyces. Science 253:1415-17 